\title{
Estradiol decreases iodide uptake by rat thyroid follicular FRTL-5 cells
}

\author{
T.W. Furlanetto ${ }^{1}$, \\ R.B. Nunes Jr. ${ }^{1}$, \\ A.M.I. Sopelsa ${ }^{1}$ \\ and R.M.B. Maciel²
}

\author{
1Divisão de Medicina Interna, Hospital de Clínicas de Porto Alegre, \\ Universidade Federal do Rio Grande do Sul, Porto Alegre, RS, Brasil \\ ${ }^{2}$ Divisão de Endocrinologia, Departamento de Medicina, \\ Universidade Federal de São Paulo, São Paulo, SP, Brasil
}

\section{Correspondence \\ T.W. Furlanetto \\ Divisão de Medicina Interna \\ Hospital de Clínicas de \\ Porto Alegre, UFRGS \\ Rua Ramiro Barcellos, 2350/700 \\ 90035-003 Porto Alegre, RS \\ Brasil \\ Fax: + 55-51-333-1585 \\ E-mail: furlanet@cpovo.net \\ Research supported by CNPq, FAPERGS and Fundo de Incentivo à Pesquisa-HCPA. Publication supported by FAPESP.}

Received July 7, 2000

Accepted 0 ctober 31, 2000

\begin{abstract}
Estradiol has well-known indirect effects on the thyroid. A direct effect of estradiol on thyroid follicular cells, increasing cell growth and reducing the expression of the sodium-iodide symporter gene, has been recently reported. The aim of the present investigation was to study the effect of estradiol on iodide uptake by thyroid follicular cells, using FRTL-5 cells as a model. Estradiol decreased basal iodide uptake by FRTL-5 cells from control levels of $2.490 \pm 0.370$ to 2.085 $\pm 0.364 \mathrm{pmol} \mathrm{I}^{-} / \mu \mathrm{g}$ DNA at $1 \mathrm{ng} / \mathrm{ml}(\mathrm{P}<0.02)$, to $1.970 \pm 0.302 \mathrm{pmol}$ $\mathrm{I}^{-} / \mu \mathrm{g}$ DNA at $10 \mathrm{ng} / \mathrm{ml}(\mathrm{P}<0.003)$, and to $2.038 \pm 0.389 \mathrm{pmol} \mathrm{I}-/ \mu \mathrm{g}$ DNA at $100 \mathrm{ng} / \mathrm{ml}(\mathrm{P}<0.02)$. In addition, $4 \mathrm{ng} / \mathrm{ml}$ estradiol decreased iodide uptake induced by $0.02 \mathrm{mIU} / \mathrm{ml}$ thyrotropin from $8.678 \pm 0.408$ to $7.312 \pm 0.506 \mathrm{pmol} \mathrm{I}^{-} / \mu \mathrm{g}$ DNA $(\mathrm{P}<0.02)$. A decrease in iodide uptake by thyroid cells caused by estradiol has not been described previously and may have a role in goiter pathogenesis.
\end{abstract}

Key words

- Iodide uptake

- Estradiol

- Thyroid

- Follicular cells

\section{Introduction}

Estradiol has a well-known indirect effect on thyroid function, increasing thyroxine-binding globulin, probably due to decreased clearance rather than increased production of thyroxine-binding globulin (1). This effect may be responsible for the variations in thyroid size during the menstrual cycle, as measured by ultrasonography (2).

A direct effect of estradiol increasing thyroid follicular cell growth and reducing the expression of the sodium-iodide symporter was recently described by one of us (3) but the net result of these actions on iodide uptake by thyroid cells is not known.

The objective of the present investigation was to study the effect of estradiol on iodide uptake by thyroid follicular cells under basal conditions and after stimulation with thyrotropin (TSH), using FRTL-5 cells as a model (4).

\section{Material and Methods}

\section{Cell culture}

FRTL-5 cells (American Type Culture Collection, Rockville, MD, USA) were maintained in Ham's F12 Coon's modified medium supplemented with 5\% calf serum (Gibco 
BRL-Life Technologies, Gaithersburg, MD, USA), $5 \mu \mathrm{g} / \mathrm{ml}$ transferrin, $10 \mu \mathrm{g} / \mathrm{ml}$ insulin, $1 \mathrm{mIU} / \mathrm{ml} \mathrm{TSH}, 1 \mu \mathrm{g} / \mathrm{ml}$ amphotericin B (Bristol-Myers Squibb, Santo Amaro, SP, Brazil) and $20 \mu \mathrm{g} / \mathrm{ml}$ amikacin (Bristol-Myers Squibb), in a humidified incubator at $37^{\circ} \mathrm{C} /$ $5 \% \mathrm{CO}_{2}$, with a change of medium every 3 to 4 days. All media contained phenol red.

\section{lodide uptake}

FRTL-5 cells $\left(5 \times 10^{5}\right.$ per well) were plated onto 24-well plates. After 4 days, cells were washed twice with warm PBS and incubated in Ham's F12 Coon's modified medium supplemented with $5 \%$ calf serum, $5 \mu \mathrm{g} / \mathrm{ml}$ transferrin, $10 \mu \mathrm{g} / \mathrm{ml}$ insulin, $1 \mu \mathrm{g} /$ $\mathrm{ml}$ amphotericin B, and $20 \mu \mathrm{g} / \mathrm{ml}$ amikacin (2H medium). After starvation for 7 days (-TSH), cells were treated as follows, in 2 different experiments:

Estradiol effect on basal iodide uptake. Control group (2H medium), group treated with $1 \mathrm{ng} / \mathrm{ml}$ estradiol $(2 \mathrm{H}+1 \mathrm{ng} / \mathrm{ml}$ estradiol), group treated with $10 \mathrm{ng} / \mathrm{ml}$ estradiol $(2 \mathrm{H}+10 \mathrm{ng} / \mathrm{ml}$ estradiol$)$, and group treated with $100 \mathrm{ng} / \mathrm{ml}$ estradiol $(2 \mathrm{H}+100 \mathrm{ng} / \mathrm{ml}$ estradiol). Twelve wells were used per treatment group. Iodide uptake was determined after $24 \mathrm{~h}$.

Estradiol effect on iodide uptake stimulated with TSH. Control group (2H medium), TSH group ( $2 \mathrm{H}$ medium $+0.02 \mathrm{mIU} / \mathrm{ml}$ $\mathrm{TSH})$, and TSH + estradiol group $(2 \mathrm{H}+0.02$ $\mathrm{mIU} / \mathrm{ml} \mathrm{TSH}+4 \mathrm{ng} / \mathrm{ml}$ estradiol). Six wells were used per treatment group. The treatment medium was changed once and iodide uptake was determined after $48 \mathrm{~h}$.

Ethanol, used as solvent for estradiol, was added as necessary so all treatment media had a $0.1 \%$ final content.

Iodide uptake was measured $48 \mathrm{~h}$ after incubation with TSH and $24 \mathrm{~h}$ after incubation with estradiol, as described previously (5). Briefly, cells were washed twice with Hanks' balanced salt solution-HEPES (HBSS$\mathrm{H}), \mathrm{pH} 7.4$, and incubated for $30 \mathrm{~min}$ at $37^{\circ} \mathrm{C}$ with $0.5 \mathrm{ml}$ of warm HBSS-H- $0.4 \%$ albumin- $10 \mu \mathrm{M}$ sodium iodide- ${ }^{125}$ I (NEN Dupont Nez-033, Boston, MA, USA), approximately $0.1 \mu \mathrm{Ci}$. After $30 \mathrm{~min}$, well content was quickly aspirated, cells were washed twice with ice-cold PBS and $1 \mathrm{ml}$ of $99 \%$ ethanol was added to each well. Plates were kept for 1-2 $\mathrm{h}$ at room temperature and the content of the wells was transferred to tubes. Radioactivity was counted for 5 min (AutogamaCobra, Packard, Downers Grove, IL, USA) in 3 tubes containing $0.5 \mathrm{ml}$ of $99 \%$ ethanol and $0.5 \mathrm{ml}$ of ${ }^{125} \mathrm{I}$ solution. Iodide uptake is reported as picomole iodide per $\mu \mathrm{g}$ DNA per well (pmol I- $/ \mu \mathrm{g}$ DNA), with the total count representing 5,000 pM of iodide. Iodide uptake was calculated using the formula: (counts observed/total count) x 5,000 pmol I- $/ \mu \mathrm{g}$ DNA.

DNA was measured by the diphenylamine method (6). After ethanol removal, cells were washed twice with cold PBS, and cold 5\% TCA was added for a period of $15 \mathrm{~min}$ to several days at $4{ }^{\circ} \mathrm{C}$. TCA was aspirated and a "developing solution" [20 ml A solution (500 mg diphenylamine $+45 \mathrm{ml}$ glacial acetic acid $\left.+1 \mathrm{ml} 18 \mathrm{M} \mathrm{H}_{2} \mathrm{SO}_{4}\right)+8 \mathrm{ml} \mathrm{ddH_{2 } \mathrm { O } +}$ $280 \mu 11 \%$ acetaldehyde] was added for $24 \mathrm{~h}$. The results were read at $580 \mathrm{~nm}$ with a spectrophotometer (Incibrás, São Paulo, SP, Brazil) and calculated according to the standards.

All experiments were repeated at least twice and gave essentially the same results. The data shown are those of a representative experiment.

All reagents, unless stated, were obtained from Sigma Chemical Co., St. Louis, MO, USA.

\section{Statistical analysis}

Nonparametric one-way analysis of variance (Kruskal-Wallis test) was used for comparison between multiple groups and the Mann-Whitney test was used to compare two groups. All P values were two-sided and 
a $P$ value of less than 0.05 was considered to indicate statistical significance.

\section{Results}

\section{Effect of estradiol on iodide uptake in the absence of TSH}

As shown in Figure 1, estradiol decreased iodide uptake at all concentrations tested compared to control (from $2.490 \pm 0.370$ to $2.085 \pm 0.364 \mathrm{pmol} \mathrm{I}-/ \mu \mathrm{g}$ DNA at $1 \mathrm{ng} / \mathrm{ml}$ $(\mathrm{P}<0.02)$, to $1.970 \pm 0.302 \mathrm{pmol}^{-} / \mu \mathrm{g}$ DNA at $10 \mathrm{ng} / \mathrm{ml}(\mathrm{P}<0.003)$, and to $2.038 \pm 0.389$ $\mathrm{pmol} \mathrm{I}^{-} / \mu \mathrm{g}$ DNA at $\left.100 \mathrm{ng} / \mathrm{ml}(\mathrm{P}<0.02)\right)$.

\section{Effect of estradiol in combination with TSH on iodide uptake}

As shown in Figure 2, $0.02 \mathrm{mIU} / \mathrm{ml} \mathrm{TSH}$ increased iodide uptake from $1.492 \pm 0.148$ to $8.678 \pm 0.408 \mathrm{pmol} \mathrm{I}^{-} / \mu \mathrm{g}$ DNA $(\mathrm{P}<0.006)$, and the addition of $4 \mathrm{ng} / \mathrm{ml}$ estradiol reduced the effect of TSH to $7.312 \pm 0.506 \mathrm{pmol} \mathrm{I}^{-} /$ $\mu \mathrm{g}$ DNA $(\mathrm{P}<0.02)$.

\section{Discussion}

In the present study we examined the effect of estradiol on iodide uptake by FRTL5 cells. A direct effect of estradiol on thyroid follicular cells was expected because estrogen receptors are present in abundant amounts in these cells (7-9).

We were able to demonstrate a decrease in iodide uptake by estradiol-treated FRTL-5 cells in the presence and absence of TSH. This effect was expected on the basis of the estradiol-induced decrease in sodium-iodide symporter gene expression observed previously in the presence of TSH, but not when estradiol alone was used (3). Nevertheless, estradiol alone was able to block iodide uptake. This apparent discrepancy may have been due to a better sensitivity of the iodide uptake technique in measuring the effect of estradiol under these conditions when com-

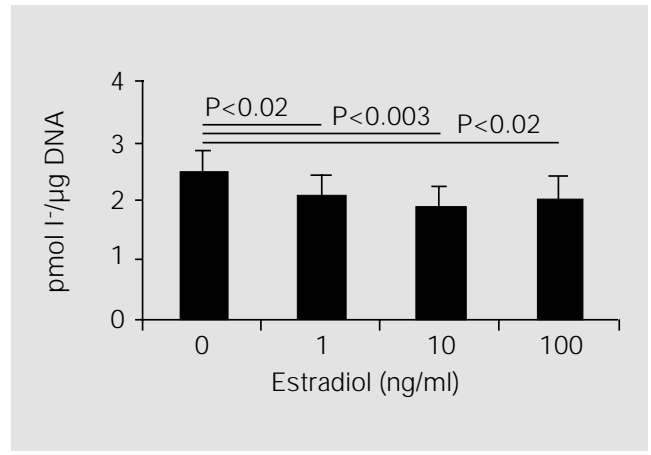

Figure 1 - Estradiol decreases basal iodide uptake in FRTL-5 cells. Cells $\left(5 \times 10^{5}\right.$ per well) were grown for 4 days in 24well plates, deprived of TSH for 7 days, and treated for $24 \mathrm{~h}$ with no estradiol, $1 \mathrm{ng} / \mathrm{ml}$ estradiol, $10 \mathrm{ng} / \mathrm{ml}$ estradiol or $100 \mathrm{ng} / \mathrm{ml}$ estradiol (12 wells per group). Results are reported as mean \pm SD. Significance levels are shown at the top of bars (MannWhitney test). TSH, Thyrotropin.

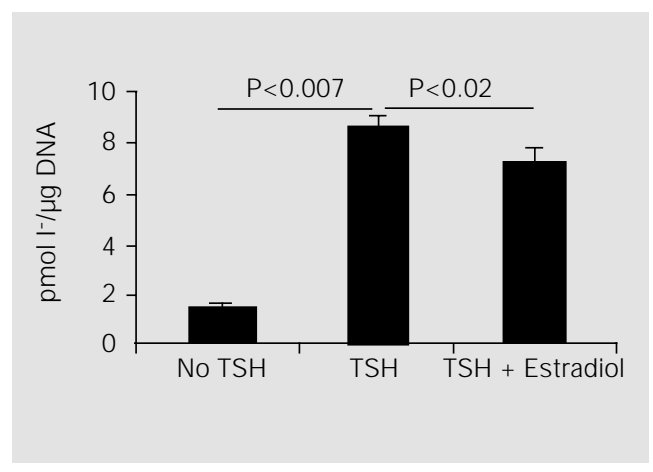

Figure 2 - Estradiol decreases TSH-stimulated iodide uptake in FRTL-5 cells. Cells $\left(5 \times 10^{5}\right.$ per well) were grown for 4 days in 24-well plates, deprived of TSH for 7 days, and treated for $48 \mathrm{~h}$ with no TSH, $0.02 \mathrm{mlU} / \mathrm{ml}$ TSH or $0.02 \mathrm{mIU} / \mathrm{ml}$ TSH associated with $4 \mathrm{ng} / \mathrm{ml}$ estradiol, with one change (6 wells per group). Results are reported as mean \pm SD. Significance levels are shown at the top of bars (MannWhitney test).

pared to the semi-quantitative method used to measure the very low sodium-iodide symporter gene expression in the absence of TSH.

This report is the first to demonstrate a decrease in iodide uptake by FRTL-5 induced by estradiol. The observed effect was quite mild and could have been influenced by the presence of estrogenic activity in the medium (steroid activity of phenol red present in the medium, or inhibitory steroids in serum). In addition, the concentrations of estradiol used were supra-physiological and experiments to study estrogen associated with an antagonist of its action were not performed, so that some nonspecific effect cannot be excluded. Nevertheless, since the decrease of the sodium-iodide symporter gene expression, described previously using similar experimental conditions, was fully reversed by ICI182780 (3), an estrogen antagonist, we would expect the same to occur for iodide uptake.

The mechanisms mediating the function 
of thyroid follicular cells are complex $(10,11)$, and how estradiol affects iodide uptake by FRTL-5 cells is not understood. Estrogen may have a direct nuclear effect on sodiumiodide symporter gene expression, associated or not with a decrease in the ability of the sodium-iodide symporter to carry iodide. Another possible explanation is the production of some estradiol-induced growth factor able to decrease iodide uptake. Some growth factors have shown this ability, like activin A (12), epidermal growth factor $(13,14)$, TGF- $\alpha$ (15) and basic fibroblast growth factor (16). Thyroid follicular cells have been shown to synthesize growth factors like IGFII (17), TGF- $\beta(18,19)$ and endothelin-1 $(20)$, and have been observed in human thyroid (21), so that estrogen-induced growth factor production could potentially help to explain the effect of estradiol.

No study has been conducted thus far to verify if the estradiol-induced iodide uptake by follicular cells is accompanied by a decrease in cell iodide content. It is well known that the decrease in iodide content of thyroid cells makes these cells more susceptible to the effects of TSH $(22,23)$. If there is a decrease in the iodide content of thyroid follicular cells induced by estradiol, this may help to explain the increased prevalence of goiter in women (24-26), even when their TSH levels do not differ from those observed in men. More studies should be done to better understand the functional interrelation of estradiol and thyroid follicular cells.

\section{Acknowledgments}

We would like to thank Dr. Margita Zakarija and Dr. J. Maxwell McKenzie (University of Miami, Miami, FL, USA) for kindly helping with the techniques.

\section{References}

1. Ain KB, Mori $Y \&$ Refetoff S (1987). Reduced clearance rate of thyroxine-binding globulin (TBG) with increased sialylation: a mechanism for estrogen induced elevation of serum TBG concentration. J ournal of Clinical Endocrinology and Metabolism, 65: 689-696.

2. Longcope $C$ (1996). The male and female reproductive systems in thyrotoxicosis. In: Braverman LE \& Utiger RD (Editors), Werner and Ingbar's The Thyroid. A Fundamental and Clinical Text. 7th edn. Lippincott-Raven, Philadelphia, New York, 671-677.

3. Furlanetto TW, Nguyen LQ \& J ameson J L (1999). Estradiol increases proliferation and down-regulates the sodium/iodide symporter gene in FRTL-5 cells. Endocrinology, 140: 5705-5711.

4. Ambesi-Impiombato FS, Parks LAM \& Coon HG (1980). Culture of hormone dependent functional epithelial cells from rat thyroids. Proceedings of the National Academy of Sciences, USA, 77: 34553459.

5. Weiss SJ , Philp NJ \& Grollman EF (1984). lodide transport in a continuous line of cultured cells from rat thyroid. Endocrinology, 114: 1090-1098.

6. J in S, Hornicek FJ , Neylan D, Zakarija M \&
McKenzie J M (1986). Evidence that adenosine $3^{\prime} 5^{\prime}$-monophosphate mediates stimulation of thyroid growth in FRTL-5 cells. Endocrinology, 119: 802-810.

7. Bonacci $R$, Pinchera $A$, Fierabracci $P$, Gigliotti A, Grasso L \& Giani C (1996). Relevance of estrogen and progesterone receptors enzyme immunoassay in malignant, benign and surrounding normal thyroid tissue. J ournal of Endocrinological Investigation, 19: 159-164.

8. Van Hoeven $\mathrm{KH}$, Menendez-Botet $\mathrm{CJ}$, Strong EW \& Huvos AG (1993). Estrogen and progesterone receptor content in human thyroid tissue. American J ournal of Clinical Pathology, 99: 175-181.

9. Jaklic BR, Rushin J \& Ghosh BC (1995). Estrogen and progesterone receptors in thyroid lesions. Annals of Surgical Oncology, 2: 429-434.

10. Dumont J E, Lamy F, Roger P \& Maenhaut C (1992). Physiological and pathological regulation of thyroid cell proliferation and differentiation by thyrotropin and other factors. Physiological Reviews, 72: 667697.

11. Vassart G\& Dumont J E (1992). The thyrotropin receptor and the regulation of thyroid function and growth. Endocrine Reviews, 13: 596-611.
12. Kotajima A, Miyamoto $Y$, Tsuruo $M$, Kosaka M \& Saito S (1995). Effects of activin $A$ on deoxyribonucleic acid synthesis, iodine metabolism and cyclic adenosine monophosphate accumulation in porcine thyroid cells. Endocrinology, 136: 1214-1218.

13. Nilsson M \& Ericson LE (1994). Effects of epidermal growth factor on basolateral iodide uptake and apical iodide permeability in filter-cultured thyroid epithelium. Endocrinology, 135: 1428-1436.

14. Kraiem Z, Sadeh O, Yosef M \& Aharon A (1995). Mutual antagonistic interactions between the thyrotropin (adenosine 3'5'monophosphate) and protein kinase $\mathrm{C} /$ epidermal growth factor (tyrosine kinase) pathways in cell proliferation and differentiation of cultured human thyroid follicles. Endocrinology, 136: 585-590.

15. Arai $M$, Tsushima $T$, Isozaki $O$, Demura $H$, Shizume K, Emoto N, Miyakawa M, Nozoe Y, Murakami H \& Ohmura E (1995). Effects of transforming growth factor $\alpha$ (TGF- $\alpha$ ) on DNA synthesis and thyrotropin-induced iodine metabolism in cultured porcine thyroid cells. European J ournal of Endocrinology, 132: 242-248.

16. Isozaki O, Emoto N, Tsushima $T$, Sato $Y$, Shizume K, Demura H, Akamizu T \& Kohn 
LD (1992). Opposite regulation of deoxyribonucleic acid synthesis and iodide uptake in rat thyroid cells by basic fibroblast growth factor: correlation with opposite regulation of c-fos and thyrotropin receptor gene expression. Endocrinology, 131: 2723-2732.

17. Maciel RM, Moses AC, Villone G, Tramontano D \& Ingbar SH (1988). Demonstration of the production and physiological role of insulin-like growth factor II in rat thyroid follicular cells in culture. J ournal of Clinical Investigation, 82:1546-1553.

18. Grubeck-Loebenstein B, Buchan G, Sadeghi $R$, Kissonerghis $M$, Londei $M$, Turner M, Pirich K, Roka R, Niederle B, Kassal $\mathrm{H}$, Waldhaust $W$ \& Feldmann $M$ (1989). Transforming growth factor beta regulates thyroid growth. Role in the pathogenesis of nontoxic goiter. J ournal of Clinical Investigation, 83: 764-770.

19. Morris 3rd J C, Ranganathan G, Hay ID, Nelson RE \& J iang NS (1988). The effects of transforming growth factor- $\beta$ on growth and differentiation of the continu- ous rat thyroid follicular cell line, FRTL-5. Endocrinology, 123: 1385-1394.

20. Tsushima $T$, Arai $M$, Isozaki $O$, Nozoe $Y$, Shizume K, Murakami H, Emoto N, Miyakawa M \& Demura H (1994). Interaction of endothelin-1 with porcine thyroid cells in culture: a possible autocrine factor regulating iodine metabolism. J ournal of Endocrinology, 142: 463-470.

21. Kimura ET, Kopp P, Zbaeren J , Asmis LM, Ruchti C, Maciel RM \& Studer H (1999). Expression of transforming growth factor B1, $B 2$ and $B 3$ in multinodular goiters and differentiated thyroid carcinoma: a comparative study. Thyroid, 9: 119-125.

22. Brabant G, Bergmann P, Kirsch CM, Kohrle J , Hesch RD \& von zur Muhlen A (1992). Early adaptation of thyrotropin and thyroglobulin secretion to experimentally decreased iodine supply in man. Metabolism, 41: 1093-1096.

23. Nagataki S \& Yokohama N (1996). Autoregulation: Effects of iodide. In: Braverman LE \& Utiger RD (Editors), Werner and Ingbar's The Thyroid. A Fundamental and Clinical Text. 7th edn. LippincottRaven, Philadelphia, New York, 241-247.

24. Tunbridge WM, Evered DC, Hall R, Appleton D, Brewis M, Clark F, Evans J G, Young E, Bird T \& Smith PA (1977). The spectrum of thyroid disease in a community: the Whickham Survey. Clinical Endocrinology, 7: 481-493.

25. Vanderpump MP, Tunbridge WM, French J M, Appleton D, Bates D, Clark F, Evans J G, Hasan DM, Rodgers H, Tunbridge F \& Young $E$ (1995). The incidence of thyroid disorders in the community: a twenty-year follow-up of the Whickham Survey. Clinical Endocrinology, 43: 55-68.

26. Laurberg P, Pedersen KM, Hreidarsson A, Sigfusson N, Iversen E \& Knudsen PR (1998). lodine intake and the pattern of thyroid disorders: a comparative epidemiological study of thyroid abnormalities in the elderly in Iceland and in J utland, Denmark. J ournal of Clinical Endocrinology and Metabolism, 83: 765-769. 